\title{
Kierkegaard on Socrates: the strength and purity of mind
}

Keywords: Kierkegaard, Socrates, neurophilosophy, mind, wisdom, human prosperity

\section{Editorial}

In his fever of continuous philosophical reflections Soeren Kierkegaard (1813-1855), paid special respect for the thinkers, who experienced the anxiety for the absolute values and followed the way of martyrdom and personal sacrifice, remaining stable with reverence on their principles and doctrines.

Among the persons who gained Kierkegaard's deep respect and veneration for their moral purity and genuine of life were Abraham, Job, St. Paul, and Socrates. Kierkegaard admired Socrates (470-399 B.C.) and esteemed him as one of the best philosophers, who endeavored to search for the truth, seeking for the absolute values, attempting to know himself, following the way of self-sacrifice eventually, for defending his principles and moral integrity. "I have admired that noble, simple wise man," wrote Kierkegaard ${ }^{1}$ and added that even during his studies in high school he felt a deep admiration reading the Socratic dialogues

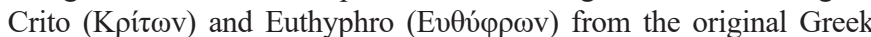
text.

Socrates was Kierkegaard's finest symbol of wisdom, simplicity, honesty, sincerity, and force of character. "Socrates was a person of reference to me...He filled my soul to overflowing. My duty was Socrates' duty" he used to say with youthful enthusiasm. ${ }^{2}$ In his diary wrote, "Socrates was the man who exercised on my personality the strongest influence, even from my early youth".,4 Kierkegaard used to study with great enthusiasm the Platonic dialogues published by Astius, ${ }^{5}$ as well as the Platonic Dictionary (Lexikon Platonikum), which was published by Schleiermacher. ${ }^{6}$ He concluded that Socrates was an archetype, a paradigm, a model of philosophical life, who dedicated his life to moral perfection, emphasizing the importance of self-knowledge.

According to Kierkegaard, the Socratic doctrines are of fundamental and lasting value for Western Civilization as well as for the continuous moral culture of the human being. He attempted to apply Socratic ethical mission and vocation for moral purity as the unique philosophical background for the strength of mind of the man of our days.

Socrates was the unique authority who combined simplicity with heroism and martyrdom. He was the pedagogue of morality, selfcontrol, and perfection, who had the strength to die for the truth. According to Kierkegaard, Socrates wrote the best chapter of existential philosophy. He wrote in his diary "Socrates is the only man, who introduced the concept of the existence"s and admitted also that his philosophical orientation was deeply inspired by the Socratic doctrines. The doctrines of a man who loved the beautiful and good ${ }^{9}$ and remained an extraordinary authority, always contemporaneous. The man of our Era needs Socratic philosophy to confront his anxiety, agony, sadness, solitude, perplexity, and weakness of mind. ${ }^{10}$

Despite Kierkegaard's deep and genuine faith and religiosity, Philosophy was an essential field of his mental life. He elevated the Socratic model on the top of his consciousness, making also a clear
Volume II Issue 4 - 202I

\author{
Stavros J Baloyannis \\ Professor Emeritus, Research Institute for Alzheimer's disease, \\ Aristotelian University, Greece
}

Correspondence: Stavros J Baloyannis, Professor Emeritus, Research Institute for Alzheimer's disease, Aristotelian University, Angelaki 5, Thessaloniki 54621, Greece, $\mathrm{Tel}+3023$ I 0270434, Fax +302310270434 Email sibh844@otenet.gr

Received: July 15, 2021 | Published: August 16, 2021

distinction between philosophical and religious life, considering that Socrates was a link between philosophy and Christian faith, like himself. "I would recognize Socrates as my Teacher, while I believe in our Lord absolutely, as my Savior" he used to say as a statement. ${ }^{11}$

Socrates traced the way of harmonious terrestrial life and the Lord opened the gate, which leads to the celestial and eternal life. Socrates claimed that human transgressions are the result of ignorance and weakness of the mind, whereas wisdom and the knowledge of truth liberate man from passions and protect him from errors. Kierkegaard strongly believed that only the Lord can save the human being from the soul's passions and the weakness of the mind, by his ineffable grace and love.

Kierkegaard's love for the absolute is characterized by two dimensions, the human one, and the divine. The human dimension was fulfilled by the Socratic philosophy and the divine one by Lord's teaching. The anxiety in Kierkegaard's philosophy manifests emphatically his thirst for the absolute truth. ${ }^{12}$

The human being needs high moral standards to feel the ethical pain and the following sadness and needs also the strength of the mind, provided by the faith to feel the hope and the happiness. ${ }^{12-14}$

Socrates was very honest in showing the beauty of the truth, without any exaggeration and emphasis, fighting at the same time against the dogmatism, prejudice, and the mental fixation, through his criticism. His contribution to Kierkegaard's freedom of mind is considerable, given that he liberated him from the ideological fixation or the continuous irrational contradictions and arguments. ${ }^{15,16}$ Socrates is the philosopher, who liberates man from moral compromise and mental inertia, seeking the purity of truth, the illumination of the mind, the self-evaluation, and self-mastering for a prudent and peaceful internal life. ${ }^{17,18}$ 
Socrates' frequent teaching by ironical dialectics was interpreted by Kierkegaard as a wise method to fight the ignorance, through the ironical flexibility and paradox, triggering at the same time the investigation of the reality, the cross-examination, the strength of self-mastering ${ }^{19}$, ${ }^{20}$ and the orientation on moral and axiological issues. The irony for Kierkegaard is a mode of infinite negative subjectivity, which might be an efficient way of teaching and motivating..$^{21,22}$

Kierkegaard learned by Socrates that all the values, virtues, and worth should be discovered inside the human soul and should be excavated from the soil of ignorance and self-indifference. ${ }^{23}$ Kierkegaard considered Socrates as a model of the real teacher with amazing integrity and honesty, who criticized the men for their ignorance and was condemned to death by them for his unceasing search of the truth. ${ }^{24,25}$

Socrates was also a noble teacher who respected the autonomy of his disciples, a fact that touched Kierkegaard profoundly. He wrote in his diary "The ideal condition of the human being is the solitude. The man living alone and independent gains the serenity of mind and the self-perfection by knowing himself and cultivating the virtues ( $\alpha \rho \varepsilon \tau \alpha \dot{\alpha} \varsigma)$ by the strength of mind, according to Socrates". 25

Socrates according to Kierkegaard was different from other philosophers, who considered themselves as wise, with plenty of knowledge, experience, and validity, whereas Socrates admitted his ignorance, emphasizing the necessity for continuous self-investigation and amelioration of the internal life. Kierkegaard's admiration for Socrates was mainly based on the fact that the greek philosopher endeavored to clarify the relationship between Mind and Being, inserting also in the existential dimension of Being. In the Platonic dialogues, Kierkegaard tried to analyze the Socratic concept of Being under the precious supervision of his professor Poul Moeller, ${ }^{26}$ who was a scholar, an expert on Platonic texts, who studied profoundly the "Socratic problem". 27,28

Kierkegaard in Platonic texts discovered himself, his real Being, $\mathrm{He}$ identified himself with the pure, noble, honest greek philosopher, who lived in simplicity and poverty, attempting to overpass the ignorance, dogmatism, and prejudice, by the self-knowledge and the strength of the mind.

\section{Acknowledgments}

None.

\section{Conflicts of interest}

The authors declare no conflicts of interest.

\section{References}

1. Kierkegaard S. Christian Discourses 1849. In: L Walter. Oxford 1940.

2. Kierkegaard S. Attack upon Christiandom 1855. In: W Lowrie. Princeton 1044. p. 283.

3. Rohde PP. Soeren Kierkegaarads dagboeger.Thavning og Apeels Forlag. Koebenhavn 1961.
4. Hong HV, Hong EH. Soeren Kierkegaard's Journals and Papers. Bloomington 1967-1977.

5. Asitus F. Platonis opera quae extant I-XI, 1819-1832.

6. Schleiermacher FW. Lexikon Platonikum; Platons Werke i-VI, 1817-1828.

7. Kierkegaard S. Letters and Documents.Vol.XXV. In: H Rosenmeier. Princeton, 1978. p.263.

8. Kierkegaard S. Journal 4301.In: Hong HV, Hong EH, editors. Soeren Kierkegaard's Journals and Papers. Bloomington 1967-1977.

9. Kierkegaard S. Works of Love 1847. In: H Hong. Princeton, 1962, p. 341.

10. Kierkegaard S. Sickness unto Death. In: W Lowrie. Princeton. 1969. p.223.

11. Kierkegaard S. The point of view of my work as an author. In. W Lowrie. New York, 1962, p.41.

12. Baloyannis SJ. The anxiety in the Kierkegaard's philosophy. Gregory Palamas. 1988;71:8-13.

13. Kierkegaard S. Christian Discourses 1849. In: L Walter Oxford 1940. p.246

14. Kierkegaard S. The Journals. In: A Dru. Oxford University Press.1938.

15. Kierkegaard S. Philosophical Fragments 1844. In: D Swenson, editor. 2nd edn, Rev.H. Hong. Princeton 1962. p.14.

16. Baloyannis SJ. The existential anxiety. Gregory Palamas. 1987;70:30-38.

17. Harf H. Reflections on Kierkegaard's Socrates. J History of Ideas. $1983 ; 44: 255-276$

18. Kierkegaard S. Philosophical Fragments 1844. In: D Swenson, editor. 2nd edn. Rev. H.Hong. 1962, p.68.

19. Kierkegaard Søren. Kierkegaard's Writings, II, Volume 2: The Concept of Irony, with. Continual Reference to Socrates/Notes of Schelling's Berlin Lectures. Vol. 76. Princeton University Press, 2013.

20. Baloyannis SJ. The psychotherapy in Ancient Greece Scien Annals Sch. Theol. AUTH 1992, pp.431-438.

21. Lageman August G. Socrates and psychotherapy. Journal of religion and health. 1989;28(3):219-223.

22. Muench P. Socratic Irony, Plato's Apology, and Kierkegaard's On the Concept of Irony. In: Niels Jørgen Cappelørn, Hermann Deuser, editors. In Kierkegaard Studies Yearbook. Berlin: Walter de Gruyter 2009. p. 71-125.

23. Kierkegaard S. Concluding Unscientific Postscript. In: D Swenson, W Lowrie, editors. Princeton 1940. p.77.

24. Howland J. Kierkegaard and Socrates: A Study in Philosophy and Faith. Cambridge: Cambridge University Press, 2006.

25. Kierkegaard S. Philosophical fragments.p.29.

26. Moeller P. Udkast Til Forelaesinger over den aeldre Philosopies Historie. Ellerladre Skifter. Koebenhavn 1839.

27. Hermann F. Geschichte und System der Platonischen Philosophie. Heidelberg 1839.

28. Himmelstrup J. Soeren Kirkegaards Opfattelse af Socrates. Koebenhavn 1924. 